\title{
Vitamin $U$ ameliorates glycoprotein components, enzyme and tissue factor activities of amiodarone toxicity in liver
}

\author{
Ismet Burcu TURKYILMAZ, Refiye YANARDAG
}

\begin{abstract}
In this study, we aimed to investigate the protective effect of Vitamin $U$ (Vit U) on amiodarone (AMD)-induced hepatotoxicity. Male Sprague-Dawley rats were randomly divided into four groups. Group I was control animals receiving corn oil for 7 days, Group II consisted of animals receiving Vit U $(50 \mathrm{mg} / \mathrm{kg}$ ) for 7 days, Group III consisted of animals receiving AMD (100 mg/kg) for 7 days and Group IV consisted of animals given AMD and Vit $U$ (in same dose and time). AMD and Vit $\mathrm{U}$ were administered to rats by gavage. On the 8 th day, all the animals fasted overnight were sacrificed. Blood and liver tissue
\end{abstract}

samples were taken from animals. Serum total cholesterol levels and liver gamma glutamyl transferase (transpeptidase) adenosine deaminase and tissue factor activities, liver glycoprotein component level such as fucose, hexose and hexosamine were determined. All the parameters were found to be increased in AMD group as compared to control group. Administration of Vit $U$ reversed these effects in AMD group. According to these results, we can conclude that Vit $\mathrm{U}$ can prevent AMD-induced liver injury.

Keywords: Amiodarone, Glycoprotein, Liver, Tissue factor, Vitamin U
Ismet Burcu TURKYILMAZ, Refiye YANARDAG

Istanbul University, Faculty of Engineering, Department of Chemistry, 34320-Avcilar, Istanbul, TURKEY

\section{Corresponding author:}

Ismet Burcu Turkyilmaz

Istanbul University, Faculty of Engineering, Department of Chemistry, 34320 Avcilar / Istanbul, TURKEY

Phone: +902124737070

Fax: +902124737180

E-mail:burcut@istanbul.edu.tr,burchemistry@gmail.com

Refiye YANARDAG

Istanbul University, Faculty of Engineering, Department of Chemistry, 34320 Avcilar / Istanbul, TURKEY

Phone:+902124737037

Fax: +902124737180

E-mail:refiyeyanardag@yahoo.com

Submitted/Gönderilme: 22.02 .2016

Accepted/Kabul: 11.03.2016
Revised/Düzeltme: 10.03.2016

\section{INTRODUCTION}

Amiodarone (AMD) is a benzofuran derivative and shows class III antiarrhythmic drug profile. This drug has been widely used for treatment of ventricular and supraventricular tachyarrhythmias (1). AMD has a long half-life and a weak bioavailability (2) and tends to accumulate in many tissue and organs. Thus side effects and toxicities occur in parts of the body with this way. The most affected organs and tissues can be numbered as liver (3), lung (4), kidney (5), thyroid (6), brain (7) and ocular tissue (8). AMD is also reported as a hepatic mitochondrial toxicant that damages electron transport system by inhibiting complex I as well as $\beta$-oxidation of fatty acids. These pathways are carrying vital value for liver. Lewis et al. (9) and Simon et al. (10) reported AMD studies that have been carried out with human and they observed micro/macrovesicular steatosis in patients during experiments. In addition to that AMD has also a tendency to produce free radicals which can be associated with its toxicity $(11,12)$.

Glycoproteins, which are primarily known as hexose, hexosamine, fucose are important components of cell 
membranes. They are composed of proteins which have carbohydrate moiety and this moiety is covalently bounded to their peptide side. The glycoproteins have many functions like mediating cell surface function, cell-cell recognition, cellular adhesion. The importance and increased levels of glycoproteins in various diseases have been reported as many researchers (13-15). The liver is a responsible organ for producing large amounts of glycoproteins present in blood (14).

Vitamin $\mathrm{U}$ (Vit $\mathrm{U}$ ) is a methionine derivative compound that is found in flowering plants (16) and in the species of Brassicaceae family (17). Although it has been called vitamin, it hasn't been accepted into vitamin classification. Besides, this compound has many useful features like hypolipidemic (18), hepatoprotective (19) and gastroprotective effects (20) and wound-healing properties (21).

In this study, we aimed to investigate protective effect of Vit $\mathrm{U}$ on glycoprotein content and enzyme activities on amiodarone induced liver injury.

\section{MATERIAL AND METHODS}

\subsection{Material}

The experimental procedures were approved by the local Animal Care and Use Committee of Istanbul University, with the certification on the Application for the Use of Animals dated September 27, 2012 (approval ID: 2012 / 127). In this study, 3.5-4 months aged male Sprague-Dawley rats (Istanbul University Experimental Medical Research and Application Institute, DETAE) were used. Their diet consisted of standard animal pellet food and tap water ad libitum. Application of AMD dose and time were determined as Reasor et al. (22). Vit $\mathrm{U}$ dose were administered according to Sokmen et al. (19). A total of twenty nine rats were divided into 4 groups as follows. The groups include: Group I, control animals receiving corn oil for 7 days $(\mathrm{n}=6)$; Group II, animals receiving Vit $\mathrm{U}(50 \mathrm{mg} / \mathrm{kg})$ for 7 days $(\mathrm{n}=7)$; Group III; animals receiving AMD $(100 \mathrm{mg} / \mathrm{kg})$ for 7 days $(\mathrm{n}=8)$; and Group IV, animals receiving Vit U $(50 \mathrm{mg} / \mathrm{kg})$ for 7 days 1 $\mathrm{h}$ prior to the administration of AMD (100 mg/kg) (n=8). $A M D$ and Vit $U$ were administered to rats by gavage. On the $8^{\text {th }}$ day, all the animals fasted overnight were sacrificed.

Biochemical investigations were made in serum samples and liver tissues of all groups. Serum total cholesterol levels were determined according to Zlatkis et al. (23). The liver tissues were taken from animals under anesthesia. Tissue samples were washed with physiological saline $(0.9 \% \mathrm{NaCl})$ and kept frozen until the day of the experiments. On the day of the experiments, liver samples were homogenized in cold $0.9 \%$ $\mathrm{NaCl}$ with a glass homogenizer to make up to a $10 \%(\mathrm{w} / \mathrm{v})$ homogenate. The homogenates were centrifuged and the clear supernatant fraction was removed for biochemical analysis. In liver homogenates, gamma glutamyl transferase (transpeptidase) activity $(\gamma-G T)$ was measured by Szasz method (24), adenosine deaminase activity was determined according to Karker (25), tissue factor (TF) activity according to Quick's one-stage method using normal plasma (26). Fucose levels of liver tissues were evaluated according to the method of Dische and Shettles (27) and hexose-hexosamine contents were estimated by the method by Winzler (28). The protein measurements in liver homogenates were determined according to Lowry et al. (29).

\subsection{Statistical Analysis}

Biochemical analysis was performed by one-way ANOVA followed by Duncan's Newman-Keuls multiple comparison test. The values are expressed as the mean \pm standart deviation (SD). P values less than 0.05 were considered to be significant.

\section{RESULTS AND DISCUSSION}

The serum total cholesterol levels and liver $\gamma-$ GT, ADA and $\mathrm{TF}$ activities were shown in Table 1. According to these results, the serum total cholesterol, liver $\gamma-\mathrm{GT}, \mathrm{ADA}$ and $\mathrm{TF}$ activities were found to be increased in AMD group as compared to control group in a significant manner $(\mathrm{P}<0.05$, $\mathrm{P}<0.0001)$. Administration of Vit $\mathrm{U}$ reversed serum total cholesterol levels insignificantly while the reverse effect of vit $\mathrm{U}$ on $\gamma-\mathrm{GT}$, ADA and TF activity was in a significant manner in AMD group $(\mathrm{P}<0.05, \mathrm{P}<0.0001)$.

In Table 2, liver fucose, hexose and hexosamine levels were seen. All the glycoprotein levels were observed to be significantly increased in AMD group when compared to control group $(\mathrm{P}<0.05)$. Vit $\mathrm{U}$ decreased all the component levels of liver in this table in a significant manner in AMD group $(\mathrm{P}<0.05)$.

The liver is a vital organ where the basic metabolic pathways like carbohydrates, lipids and proteins as well as detoxification of xenobiotic substances occur. This situation brings it to be a target organ for toxicity. As being reported in literature by Seeff (30) and Jaeschke (31), drug induced liver injury becomes a big problem day by day. So finding new solutions to prevent drug induced liver injury become important.

The liver has an importance for cholesterol and lipid metabolism. AMD is a phospholipase inhibitor and causes lipid accumulation in the liver. The studies that support this 
Table 1. The serum total cholesterol levels, and the liver gamma glutamyl transferase ( $\gamma-G T)$, adenosine deaminase (ADA) and tissue factor (TF) activities of control and experimental groups

\begin{tabular}{ccccc}
\hline Groups & $\begin{array}{c}\text { Total Cholesterol } \\
(\mathbf{m g} / \mathbf{d L})^{*}\end{array}$ & $\begin{array}{c}\gamma-\text { GT } \\
(\mathbf{U} / \text { g protein })^{*}\end{array}$ & $\begin{array}{c}\text { ADA } \\
(\text { U/g protein })^{*}\end{array}$ & $\begin{array}{c}\text { TF } \\
(\text { second })^{*}\end{array}$ \\
\hline Control & $43.25 \pm 8.68$ & $19.97 \pm 8.06$ & $8.40 \pm 1.29$ & $207.60 \pm 20.90$ \\
Control + Vit U & $51.16 \pm 8.24$ & $23.52 \pm 6.91$ & $15.63 \pm 6.08$ & $181.30 \pm 9.83^{\mathrm{a}}$ \\
Amiodarone & $57.81 \pm 9.36^{\mathrm{a}}$ & $33.16 \pm 4.77^{\mathrm{a}}$ & $14.49 \pm 1.64^{\mathrm{c}}$ & $110.42 \pm 10.56^{\mathrm{c}}$ \\
Amiodarone + Vit U & $54.69 \pm 4.32$ & $24.59 \pm 2.79^{\mathrm{b}}$ & $9.57 \pm 2.16^{\mathrm{b}}$ & $210.81 \pm 14.07^{\mathrm{d}}$ \\
\hline
\end{tabular}

${ }^{*}$ Mean \pm SD

${ }^{\text {a }} \mathrm{P}<0.05$ versus control group, ${ }^{\mathrm{b}} \mathrm{P}<0.05$ versus amiodarone group, ${ }^{\mathrm{c}} \mathrm{P}<0.0001$ versus control group, ${ }^{\mathrm{d}} \mathrm{P}<0.0001$ versus amiodarone group.

Table 2. The liver fucose, hexose and hexosamine levels of control and experimental groups

\begin{tabular}{|c|c|c|c|}
\hline Groups & $\begin{array}{c}\text { Fucose } \\
(\mu \mathrm{g} \text { fucose } / \mathrm{mg} \text { protein })^{*}\end{array}$ & $\begin{array}{c}\text { Hexose } \\
(\mathrm{mg} \text { glucose/mg protein })^{*}\end{array}$ & $\begin{array}{c}\text { Hexosamine } \\
(\mu \mathrm{g} \text { glucosamine } / \mathrm{mg} \text { protein })^{*}\end{array}$ \\
\hline Control & $0.18 \pm 0.05$ & $0.26 \pm 0.04$ & $0.47 \pm 0.15$ \\
\hline Control + Vit U & $0.22 \pm 0.01$ & $0.30 \pm 0.01$ & $0.26 \pm 0.21$ \\
\hline Amiodarone & $0.50 \pm 0.08^{\mathrm{a}}$ & $0.41 \pm 0.08^{\mathrm{a}}$ & $1.14 \pm 0.39^{\mathrm{a}}$ \\
\hline Amiodarone + Vit $U$ & $0.24 \pm 0.12^{\mathrm{b}}$ & $0.25 \pm 0.08^{\mathrm{b}}$ & $0.19 \pm 0.12^{\mathrm{b}}$ \\
\hline
\end{tabular}

${ }^{\star}$ Mean \pm SD

${ }^{a} \mathrm{P}<0.05$ versus control group, ${ }^{\text {b }}<0.05$ versus amiodarone group

idea especially associated with AMD hepatotoxicity have been published by many reporters (32-34). In parallel to this approach, we got elevated serum total cholesterol levels in AMD group according to the control group. Administration of Vit $U$ decreased this level in AMD group. Seri et al. reported hypolipidemic effect of Vit $U$ via helping the acceleration of lipid molecule excretion (35). We may suggest that Vit $\mathrm{U}$ reduced serum cholesterol levels via this way.

$\gamma$-GT is an enzyme which catalyzes the breakdown of glutathione, using its gamma glutamyl part for transporting free amino acids across the membrane and into the cell (36). The importance of $\gamma-\mathrm{GT}$ is being a marker enzyme for hepatic injury which is induced by drugs and this enzyme carries weight with in clinical practice. Some reporters have reported elevated $\gamma$-GT activity levels in various either human hepatocyte culture studies induced by amiodarone or chemical-induced hepatotoxicity cases (37-39). Increased activity of this enzyme shows impairment for membrane integrity. In our study, as parallel to these reports, we found elevated activity of $\gamma-G T$ in the AMD group as we compared to the control group. However, administration of Vit $U$ reversed this activity in the AMD group. The decreased activities of this enzyme in this group may be due to membrane repair property of Vit $\mathrm{U}$ which was reported before by Racz et al (17).

$\mathrm{ADA}$ is an important aminohydrolase in the purine metabolism which catalyzes deamination of either adenosine or deoxyadenosine to inosine or deoxyinosine. This reaction is one of the rate limiting steps in adenosine degradation (40). Increased activity of this enzyme indicates liver failure (41). In the present study, we got elevated ADA activity in AMD groups compared to control group. Vit $U$ decreased this activity in AMD group. Elevated ADA activity may be associated with increased free radical levels caused by amiodarone. So we may suggest that Vit $U$ showed its antioxidant activity by decreasing this enzyme activity in AMD group.

TF (tissue factor) is the principal cellular initiator of normal blood. It is a low molecular weight glycoprotein and a component of cell membrane. An increase in the activity of TF correlates with an increase in blood coagulation levels and a decrease in coagulation time. This elevated activity is also associated with alterations which occur in cell membrane due to either membrane composition or increased lipid peroxidation levels $(42,43)$. Increased $\mathrm{TF}$ activity has been 
reported in many diseases such as diabetes, hyperlipidemia, atherosclerosis and kidney diseases $(44,45)$. In our study, TF activity was significantly increased in the AMD group when compared to the control group. Vit $\mathrm{U}$ reversed this activity in AMD group. We may suggest this reducing effect can be associated with the protective effect of Vit $\mathrm{U}$ on membrane stability (17).

Glycoproteins are compounds that include carbohydrate moiety attached to peptide side of proteins. They are present in the extracellular matrix and believed to contribute to the structure of the matrix. They play an important role in tissue stabilization and are found as hormones, blood group substances $(13,46)$. Their levels are important for determining many diseases like tuberculosis (47), autoimmune thyroiditis (48), diabetes mellitus (49) and hepatotoxicity (50). In the present study, we determined the glycoproteins like fucose, hexose and hexosamine levels of liver tissue. Levels of all the glycoproteins were found to be increased in the AMD group when compared to the control group. The elevation we have observed in the glycoprotein components of the AMD group may be a sign of a pathological process which results in the deposition of macromolecular components. This situation can be explained as cationic amphiphilic property of AMD. The hydrophobic ring structure and the hydrophilic side chain with a charged cationic amine group describe the nature of AMD. In addition to these properties, the halogen part of

Vitamin $U$ karaciğerde amiodaron toksisitesinin glikoprotein düzeyi, enzim ve doku faktör aktivitelerini iyileştirir

ÖZ

$\mathrm{Bu}$ çalışmada, amiodarone (AMD) ile oluşturulan hepatotoksisite üzerine U Vitamini (Vit U)'nin koruyucu etkisi araştırıldı. Erkek Sprague-Dawley sıçanlar rastgele dört gruba ayrıldı. Grup I; 7 gün boyunca mısır özü yağı verilen kontrol grubu, Grup 2; 7 gün boyunca Vit U (50 mg/kg) verilen hayvanlar, Grup III; 7 gün boyunca AMD (100 mg/kg) verilen hayvanlar ve Grup IV; aynı doz ve sürede $A M D$ ve Vit $U$ verilen hayvanlar. AMD ve Vit U sıçanlara gavaj yöntemiyle verildi.
AMD enhances lipophilic character and provides to interact with membrane structure. So the membrane penetrability is affected by AMD. In a similar manner, administration of Vit $U$ decreased these effects in the AMD group. We may suggest that Vit $\mathrm{U}$ exerted a protective effect on glycoprotein structure of the liver tissue due to its hypolipidemic effect which decreases lipid peroxidation levels, affecting the membrane stabilization.

\section{CONCLUSION}

This study shows that AMD induced hepatotoxicity can be prevented by Vit $\mathrm{U}$, a methionine derivative substance. This protective effect of Vit $\mathrm{U}$ may be due to its antioxidant effect and membrane stabilizing property. In conclusion, we can suggest Vit $U$ may be used on preventing AMD-induced hepatotoxicity.

\section{ACKNOWLEDGEMENTS}

This study was supported by The Scientific Research Projects Coordination Unit of Istanbul University. Project Number: 25537.

\section{CONFLICT OF INTEREST}

The authors declare that there are no conflicts of interest.
Sekizinci gün, bir gece aç bırakılan bütün hayvanlar sakrifiye edildi. Hayvanlardan kan ve karaciğer örnekleri alındı. Serum total kolesterol seviyeleri ile karaciğer gama glutamil transferaz, adenozin dezaminaz ve doku faktörü aktiviteleri, fukoz, heksoz ve heksozamin gibi karaciğer glikoprotein düzeyleri tayin edildi. $\mathrm{Bu}$ parametrelerin hepsi, kontrol grubu ile karşılaştırıldığında AMD grubunda artış olduğu görüldü. Vit U verilmesi, AMD grubunda bu değerleri tersine çevirdi. Bu sonuçlara göre, AMD ile oluşturulan karaciğer hasarını U vitamininin önlediği sonucuna varabiliriz.

Anahtar kelimeler: Amiodaron, Glikoprotein, Karaciğer, Doku Faktörü, Vitamin U

\section{REFERENCES}

1. Nasser M, Larsen TR, Waanbah B, Sidiqi I, McCullough PA. Hyperacute drug-induced hepatitis with intravenous amiodarone: Case resport and review of the literature. Drug Healthc Patient Saf 2013; 5: 191-8.

2. Babatin M, Lee SS, Pollak PT. Amiodarone hepatotoxicity.

Curr Vasc Pharmacol 2008; 6: 228-36.

3. Vitins AP, Kienhuis AS, Speksnijder EN, Roodbergen M, Lujiten M, van der Ven LT. Mechanisms of amiodarone and valproic acid induced liver steatosis in mouse in vivo act as a template for other hepatotoxicity models. Arch Toxicol 2014; 88: 1573-88.

4. Valcheva-Kuzmanova S, Stavreva G, Dancheva V, Terziev L, 
Atanasova M, Stoyanova A, Dimitrova A, Shopova V. Effect of Aronia melanocarpa fruit juice on amiodarone-induced pneumotoxicity in rats. Pharmacogn Mag 2014; 10: 132-40.

5. Luciani R, Falcone C, Principe F, Punzo G, Menè P. Acute renal failure due to amiodarone-induced hypothyroidism. Clin Nephrol 2009; 72: 79-80.

6. Jabrocka-Hybel A, Bednarczuk T, Bartalena L, Pach D, Ruchala M, Kamiński G, Kostecka-Matyja M, HubalewskaDydejczyk A. Amiodarone and the thyroid. Endokrynol Pol 2015; 66: 176-86.

7. Pomponio G, Zurich MG, Schultz L, Weiss DG, Romanelli L, Gramowski-Voss A, Di Consiglio E, Testai E. Amiodarone biokinetics, the formation of its major oxidative metabolite and neurotoxicity after acute and repeated exposure of brain cell cultures. Toxicol In Vitro 2015; 30: 192-202.

8. Turk U, Turk BG, Yilmaz SG, Tuncer E, Alioglu E, Dereli T. Amiodarone-induced multiorgan toxicity with ocular findings on confocal microscopy. Middle East Afr J Ophthalmol 2015; 22: $258-60$.

9. Lewis JH, Mullick F, Ishak KG, Ranard RC, Ragsdale B, Perse RM, Rusnock EJ, Wolke A, Benjamin SB, Seeff LB. Histopathologic analysis of suspected amiodarone hepatotoxicity. Hum Pathol 1990; 21: 59-67.

10. Simon JB, Manley PN, Brien JF, Armstrong PW. Amiodarone hepatotoxicity simulating alcoholic liver disease. N Engl J Med 1984; 311: 167-72.

11. Ray SD, Patel D, Wong V, Bagchi D. In vivo protection of dna damage associated apoptotic and necrotic cell deaths during acetaminophen-induced nephrotoxicity, amiodaroneinduced lung toxicity and doxorubicin-induced cardiotoxicity by a novel IH636 grape seed proanthocyanidin extract. Res Commun Mol Pathol Pharmacol 2000; 107: 137-66.

12. Ruch RJ, Bandyopadhyay S, Somani P, Klaunig JE. Evaluation of amiodarone free radical toxicity in rat hepatocytes. Toxicol Lett 1991; 56: 117-26.

13. Punithavathi VR, Prince PS. Combined effects of quercetin and alpha-tocopherol on lipids and glycoprotein components in isoproterenol induced myocardial infarcted Wistar rats. Chem Biol Interact 2009; 181: 322-7.

14. Saravanan G, Ponmurugan P, Senthil Kumar GP, Rajarajan T. Antidiabetic effect of S-allylcysteine: Effect on plasma and tissue glycoproteins in experimental diabetes. Phytomedicine 2010; 17: 1086-89.

15. Anadakumar P, Jagan S, Kamaraj S, Ramakrishnan G, Titto AA, Devaki T. Beneficial influence of capsaicin on lipid peroxidation, membrane-bound enzymes and glycoprotein profile during experimental lung carcinogenesis. J Pharm Pharmacol 2008; 60: 803-8.

16. Lee NY, Park KY, Min HJ, Song KY, Lim YY, Park J, Kim BJ, Kim MN. Inhibitory effect of Vitamin U (S-methylmethionine sulfonium chloride) on differentiation in 3T3-L1 preadipocyte cell lines. Ann Dermatol 2012; 24: 39-44.

17. Racz I, Paldi E, Szalai G, Janda T, Pal M, Lasztity D. $\mathrm{S}$-methylmethionine reduces cell membrane damage in higher plants exposed to low-temperature stress. J Plant Physiol 2008; 165: 1483-90.
18. Seri K, Matsuo T, Asano M, Sato R, Kato T. Hypolipidemic effects of S-methylmethioine (Vitamin U) using various experimental procedures. Arzneimittelforschung 1978; 28: 1711-2.

19. Sokmen BB, Tunali S, Yanardag R. Food Chem. Toxicol 2012; 50: 3562-6.

20. Ichikawa T, Ito Y, Saegusa Y, Iwai T, Goso Y, Ikezawa T, Ishihara $\mathrm{K}$. Effects of combination treatment with famotidine and methylmethionine sulfonium chloride on the mucus barrier of rat gastric mucosa, J Gastroenterol Hepatol 2009; 24: 488-92.

21. Kim WS, Yang YJ, Min HG, Song MG, Lee JS, Park KY, Kim, JJ, Sung JH, Choi JS, Cha HJ. Accelerated wound healing by S-methylmethionine sulfonium: Evidence of dermal fibroblast activation via the ERK1/2 pathway. Pharmacology 2010; 85: 68-76.

22. Reasor MJ, McCloud CM, Beard TL, Ebert DC, Kacew S, Gardner MF, Aldem KA, Hostetler KY. Comparative evaluation of amiodarone-induced phospholipidosis and drug accumulation in Fischer-344 and Sprague-Dawley rats. Toxicology 1996; 106: 139-47.

23. Zlatkis A, Zak B, Boyle AJ. A new method for the direct determination of serum cholesterol. J Lab Clin Med 1953; 41: 486-92.

24. Szasz G. A kinetic photometric method for serum $\gamma$-glutamyl transpeptidase. Clin Chem 1969; 15: 124-36.

25. Karker H. Method for estimation of serum adenosine desaminase. Scand J Clin Lab Invest 1964; 16: 570-4.

26. Ingram GIC, Hills M. Reference method for the one-stage prothrombin time test on human blood. International committee for standardization in hematology. Thromb Haemost 1976; 36: 237-8.

27. Dische Z, Shettles LB. A specific color reaction of methylpentoses and a spectrophotometric micromethod for their determination. J Biol Chem 1948; 175: 593-603.

28. Winzler RJ. Determination of serum glycoproteins. In: Methods of Biochemical Analysis. Editor: Glick DP. Interscience Publishers, Inc. NewYork. 1955, pp. 279-311.

29. Lowry OH, Rosebrough HJ, Farr AL, Randall RJ. Protein measurement with the Folin phenol reagent. J Biol Chem 1951; 193: 265-75.

30. Seeff LB. Drug-induced liver injury is a major risk for new drugs. Dig Dis 2015; 33: 458-63.

31. Jaeschke H. Acetaminophen: dose-dependent drug hepatotoxicity and acute liver failure in patients. Dig Dis 2015; 33: 464-71.

32. Kannan R, Pollak A, Singh BN. Elevation of serum lipids after chronic administration of amiodarone in rabbits. Atherosclerosis 1982; 44: 19-26.

33. Kasim SE, Bagchi N, Brown TR, Khilnani S, Jackson K, Steinman RT, Lehmann MH. Amiodarone-induced changes in lipid metabolism. Horm Metab Res 1990; 22: 285-8.

34. Hudig G, Bakker O, Wiersinga WM. Amidoarone-induced hypercholesterolemia is associated with a decrease in liver LDL receptor mRNA. FEBS Letters 1994; 341: 86-90.

35. Seri K. Matsuo T, Taniguchi T, Amemiya K, Kudo M, Saito 
G, Kato M. Hypolipidemic effects of S-methylmethionine (vitamin U) using various experimental procedures. Arzneimittelforschung 1980; 30: 1694-703.

36. Aksakal E, Tanboga IH, Kurt M, Kaygın MA, Kaya A, Isik T, Ekinci M, Sevimli S, Acikel M. The relation of serum gammaglutamyl transferase leves with coronary lesion complexity and long-term outcome in patients with stable coronary artery disease. Atherosclerosis 2012; 221: 596-601.

37. Belaid-Nouira Y, Bakhta H, Haouas Z, Flehi-Slim I, Neffati F, Najjar MF, Cheikh HB. Fenugreek seeds, a hepatoprotector forage crop against chronic $\mathrm{AlCl}_{3}$ toxicity. BMC Vet Res 2013; 9: 1-9.

38. Müller LG, Pase CS, Reckziegel P, Barcelos RC, Boufleur N, Prado AC, Fett R, Block JM, Pavanato MA, Bauermann LF, Da Rocha JB, Burger ME. Hepatoprotective effects of pecan nut shells on ethanol-induced liver damage. Exp Toxicol Pathol 2013; 65: 165-71.

39. Borlak J, Chougule A, Singh PK. How useful are clinical liver function tests in in vitro human hepatotoxicities assays?. Toxicology 2014; 28: 784-95.

40. Aghaei M, Karami-Tehrani F, Salami S, Atri M. Adenosine deaminase activity in serum and malignant tumors of breast cancer: the assessment of isoenzyme ADA1 and ADA2 activities. Clin Biochem 2005; 38: 887-91.

41. Sehitoglu I, Tumkaya L, Bedir R, Ozer E, Cure MC, Kalkan Y, Yuce S, Cure E. Protective effect of infliximab against carbon tetrachloride-induced hepatotoxicity. J Environ Pathol Toxicol Oncol 2015; 34: 175-82.

42. Bächli E. History of tissue factor. Br J Haematol 2000; 110 : 248-55.
43. Danese S, Papa A, Saibeni S, Repici A, Malesci A, Vecchi M. Inflammation and coagulation in inflammatory bowel disease: The clot thickens. Am J Gastroenterol 2007; 102: 174-86.

44. Emekli-Alturfan E, Kasikci E, Yarat A. Tissue factor activities of streptozotocin induced diabetic rat and the effect of peanut consumption. Diabetes Metab Res Rev 2007; 23: 653-8.

45. Minus P, Patrignani P, Gaino S, Degan M, Meapace L, Tommasoli R, Seta F, Capone ML, Tacconelli S, Palatresi S, Bencini C, Del Vecchio C, Mansueto G, Arosio E, Santonastaso CL, Lechi A, Morganti A, Patrono C. Increased oxidative stress and platelet activation in patients with hypertension and renovascular disease. Circulation 2002; 106: 2800-5.

46. Thakkar V, Patel P, Prajapati N, Kaur R, Nandave M. Serum levels of glycoproteins are elevated in patients with ovarian cancer. Indian J Clin Biochem, 2014; 29: 345-50.

47. Sonawane A, Mohanty S, Jagannathan L, Bekolay A, Banerjee $S$. Role of glycans and glycoproteins in disease development by Mycobacterium tuberculosis. Crit Rev Microbiol 2012; 38 : 250-66.

48. Janega P, Cerná A, Kholová I, Brabencová E, Babál P. Sialic acid expression in autoimmune thyroiditis. Acta Histochem 2002; 104: 343-7.

49. Veeramani C, Al-Numair KS, Alsaif MA, Chandramnohan G, Al-Numair NS, Pugalendi KV. Protective effect of CArdiospermum halicacabum leaf extract on glycoprotein components on STZ-induced hyperglycemic rats. Asian Pac J Trop Med, 2012; 5: 939-44.

50. Senthilkumar R, Nalini N. The potential beneficial effect of glycine on the carbohydrate moieties of glycoproteins in an experimental model of alcohol-induced hepatotoxicity. J Med Food 2004; 7: 108-13. 